\title{
Performance Of Chilean ADRs On The New York Stock Exchange
}

R. Stephen Elliott, Northwestern State University, USA

Mark Schaub, Northwestern State University, USA

Robert Jones, Northwestern State University, USA

\begin{abstract}
In this study, we examine NYSE-listed American Depository Receipts from Chile to determine overall short and long-term investment performance and whether the type of issue (IPO versus $S E O)$ affects $A D R$ performance relative to the $S \& P$ 500. Short-term performance suggests Chilean ADRs did not perform significantly different than the market index. However, the Chilean ADRs significantly underperformed the $S \& P 500$ by over 32 percent during the three-year trading horizon. In comparing long-run excess returns of SEOs versus those of IPOs, the SEO subset performed similar to the market while the IPOs significantly underperformed the market index by 45 percent. These results provide evidence that the type of issue (IPO versus SEO) affects portfolio returns when investing in Chilean ADRs.
\end{abstract}

Keywords: American Depository Receipts; Initial Public Offerings; Seasoned Equity Offerings; Chile; International Diversification

\section{INTRODUCTION}

ith the growth of free trade and free-trade agreements, firms in these countries may become more
competitive and therefore increase productivity and profitability. NAFTA brought together the US,
Canada and Mexico in an agreement meant to provide a preferential trading environment for these countries. The establishment of the Central American Free Trade Agreement (CAFTA) on July 27, 2005 paves the way for the eventual development of the hemispheric 34 country Free Trade Areas for the Americas. The U.S. is currently negotiating free trade with Chile, Panama, Bolivia, Columbia, and Peru. Chile is a country almost twice the size of Montana and has a population of nearly 16.5 million people. With a market economy and a reputation of strong financial institutions and fiscal policy, Chile has the strongest bond rating of any country in South America and has trade agreements with 57 other countries (The World Factbook, 2008). This leads to the question of how American Depository Receipts (ADRs) from this region performed relative to the S\&P 500. Does it matter whether the ADR is an initial public offering (IPO) or a seasoned equity offering (SEO)? In this study, we examine early and long-term performance of Chilean ADRs listed on the New York Stock Exchange to determine whether U.S. investors gain diversification and return benefits from investing in firms headquartered in this small South American country. The study begins with the review of the literature followed by the problem, methodology, findings, and conclusion.

\section{LITERATURE REVIEW}

Previous studies show mixed findings in ADR performance. Whether classified as IPOs, SEOs, or from developed countries or emerging markets, ADRs may under-perform, outperform or perform similar to the U.S. market. According to a study by Surz (2007) ADRs outperform the S\&P 500 Index by 16 percent. Sundaram and Logue (1996) conclude that in early trading ADRs provide significant positive abnormal returns. In a sample of 66 ADRs from 18 countries, Callaghan, Kleiman and Sahu (1999) find that ADRs significantly outperform the U.S. market index by 19.6 percent during a 12 month holding-period. In addition, the authors find that ADRs from emerging markets outperform ADRs from developed markets. In contrast, during a 36-month holding-period, Elliott 
and Schaub (2005) find that financial institution ADRs from developed markets outperform the S\&P 500 Index while ADRs from emerging markets perform similar to the market index. Examining the effects of market timing, Schaub and Highfield (2006) discover that emerging market ADRs issued during a bull market under-perform the S\&P 500 Index while ADRs issued during a bear market outperform the market index.

ADRs may not always outperform the market. By examining 333 ADRs from 35 countries, Foerster and Karolyi (2000) find that during a 3-year holding-period following the date of issue ADRs under-perform the U.S. market index by 27.5 percent. Likewise, Schaub (2003) concludes that during a 3-year holding period ADRs from emerging markets under-perform the S\&P 500 Index by 28 percent and ADRs from developed markets underperform the market by 11 percent. Studies by Ritter (1991), Alexander, Eun, and Janakiramanan (1988), and Brav and Gompers (1997) conclude that foreign equities under-perform the market in the long-run.

Related ADR studies based on the long-run performance of foreign equities by country of origin such as Latin America (Aggarwal, Leal and Hernandez, 1993), Taiwan (Huang, 1999), and the United Kingdom (Lewis, 1993) find that IPOs typically under-perform the market. Schaub (2002) finds that Mexican ADRs under-perform the S\&P 500 Index during a five year holding-period. On the other hand, Chinese ADRs tend to perform similar to the S\&P 500 Index during a 36-month holding period following the date of issue (Schaub, 2008). Other studies (Ben Naceur, 2000, and Dawson, 1987) conclude that IPOs outperform the market during long-run holding periods. In a study of manufacturing firm ADRs, Elliott and Schaub (2008) find that IPOs outperform the S\&P 500 Index by 5 percent over a 21-day holding period. With more than 1700 ADRs traded on American stock exchanges (Brigham and Ehrhardt, 2005), investors who embrace the concept of trading ADRs may reap the advantages of global diversification (Officer and Hoffmeister, 1988 and Jiang, 1998). The literature indicates that ADR performance tends to differ because of market timing, initial public offering, seasoned equity offering, industry, and country of origin.

\section{THE PROBLEM}

The problem of this study is to determine whether Chilean equities newly listed as ADRs on the New York Stock Exchange generally outperform the S\&P 500 Index over a 21-day and 36-month period following the date of issue. In addition, the problem is to determine whether the Chilean ADRs classified as initial public offerings (IPOs) or seasoned equity offerings (SEOs) outperform the market.

\section{METHODS AND ANALYSIS}

The Chilean ADR sample is derived from the NYSE web site which identifies non-US firms traded on the New York Stock Exchange. A total of 24 ADRs listed from January 1, 1987 through December 31, 2001 comprise the sample. Of the 24 ADRs, 5 were seasoned equity offerings (SEOs) and 19 were initial public offerings (IPOs).

Standard ADR event study methodology used for computing ADR returns, market returns, excess returns and testing of the returns are found in Schaub (2003). The S\&P 500 represents the market return because the ADRs sampled are large firms listed on the NYSE and because the S\&P 500 represents an average investor's easily attainable market performance measure. Daily and monthly returns for each security were first computed. Then the coinciding returns of the S\&P 500 for the first 21 days after listing (short-term) and the first 36 months after listing (long-term) were subtracted to produce excess returns. These excess returns were cumulated on a daily and monthly basis and tested for significance.

Equations 1 through 3 describe how excess returns and cumulative returns were computed for statistical testing. In Equation 1, the excess return for each security $\mathrm{i}$ on day/month $\mathrm{t}\left(\mathrm{xr}_{\mathrm{it}}\right)$ is computed as the difference between the return of the security on day/month $t\left(r_{i t}\right)$ and the return of the market on day/month $t\left(r_{m t}\right)$.

$$
x r_{i t}=r_{i t}-r_{m t}
$$


Equation 2 shows the average excess return for the sample on day/month $t\left(\mathrm{XR}_{t}\right)$ is computed as the simple average of the sum of excess returns of each of the ADRs on day/month $t$.

$$
X R_{t}=\frac{1}{n} \sum_{i=1}^{n} x r_{i t}
$$

Cumulative excess returns as of day/month $\mathrm{s}$ are the summation of average excess returns starting at day/month 1 until day/month s, where s ends on day 21 and month 36 respectively as shown in Equation 3.

$$
C X R_{1, s}=\sum_{t=1}^{s} X R_{t}
$$

The average excess returns and cumulative excess returns were tested to determine significance using a Z-score. Reported P-values determine significance at the .10 alpha level.

\section{FINDINGS}

Table 1 shows that in early trading over a 21-day holding period the entire ADR sample performs similar to the $\mathrm{S} \& \mathrm{P} 500$ index. Cumulative excess returns are not significantly different from the market returns on the $21^{\text {st }}$ day or any day during the period. However, by segmenting the ADRs into SEOs and IPOs, the data reveal that SEOs earn significant positive cumulative excess returns on days 2-19. The SEOs outperform the S\&P 500 index by a range of 2.55 percent on day 2 to 9.68 percent on day 10 . On the $21^{\text {st }}$ day however, the SEOs end the period with performance similar to the market index. On the other hand, the IPOs show significant negative returns on days 7 , and 10-15, then ends the 21-day holding period with performance that is similar to the market. Significant negative returns ranged from -1.53 percent on day 7 to -2.71 percent on day 14 .

During the long-run holding period of 36 months as shown in Table 2, the entire ADR sample underperforms the market. Cumulative excess returns end the 3-year period with significant negative earnings of 32.42 percent. SEOs earn significant positive returns during months 1 and 2 of 6.93 and 13.04 percent respectively, but end the 36-month period with cumulative excess returns that are similar to the S\&P 500 Index. The IPOs however show significant negative cumulative excess returns in months 13-17 and 19-36. Returns ranged from 15.09 percent to -46.54 percent.

\section{CONCLUSION}

Although the entire ADR portfolio performs similar to the S\&P 500 index in early trading, SEOs tend to outperform the IPOs. The Chilean SEOs produce significant positive returns during eighteen of the 21-day holding period while IPOs show significant negative returns for seven days. Findings suggest that although Chilean ADRs appear to perform similar to the market, there is a difference in SEO and IPO performance in the short-run.

At the end of the 36-month holding period, the entire ADR portfolio significantly underperforms the market. These findings are consistent with those of Ritter (1991), Foerster and Karolyi (2000), Schaub (2003), and Brav and Gompers (1997). Again, long-run performance reveals that SEO returns differ from IPOs. While the SEOs perform similar to the market index, the IPOs show large significant negative returns. Obviously, the ADR portfolio underperforms the market primarily because of large negative IPO returns. Evidence suggests that in the short-run and long-term holding period the type of issue (Chilean SEOs or IPOs) may determine ADR portfolio performance.

Because of differing findings, further research is needed to determine trends in ADR performance such as, industry, country of origin, type of issue, and timing of holding period in order to enhance practitioner investment returns. 


\section{AUTHOR INFORMATION}

R. Stephen Elliott is Professor of Finance in the College of Business at Northwestern State University in Natchitoches, Louisiana, and is the Kilpatrick Life Insurance Company Endowed Professor of Insurance. Dr. Elliott's research has focused on topics in insurance, personal finance, and investments. He has presented papers at national and international conferences across the United States and Mexico and has research published in numerous national and international refereed journals and conference Proceedings. He is a Certified Real Estate Instructor, and licensed in insurance and real estate. He holds a Ph.D. in Business Economics and Finance from Louisiana Tech University.

Mark Schaub is the Capital One Bank Endowed Professor of Finance at Northwestern State University of Louisiana. Dr. Schaub's previous research, published in over 30 different journals in the last 7 years, has been in the areas of consumer finance, international investments and stock market efficiency. His doctorate in Finance was earned from Mississippi State University in 1998.

Robert C. Jones III received his Ph.D. in Economics from the University of California at Los Angeles, and is currently an Associate Professor of Economics at Northwestern State University of Louisiana. His research interests include the economics of communication, economic education, and finance education.

\section{REFERENCES}

1. Aggarwal, R., R. Leal and L. Hernandez. (1993). The Aftermarket Performance of Initial Public Offerings in Latin America. Financial Management. 22: 42-53.

2. Alexander, Gordon J., Cheol S. Eun, and S. Janakiramanan. (1988). International Listings and Stock Returns: Some Empirical Evidence. Journal of Financial and Quantitative Analysis. 135-151.

3. Ben Naceur, S. (2000). An Examination of the Tunisian IPO Pricing in the Short and Long Run: 19921997. Applied Economics Letters. 7: 293-296.

4. Brav, A. and P. Gompers. (1997). Myth or Reality? The Long-Run Underperformance of Initial Public Offerings: Evidence from Venture and Nonventure Capital-Backed Companies. Journal of Finance. 52: 1791-1821.

5. Brigham, Eugene, F. and Ehrhardt, Michael C. (2005). Financial Management, 11th Edition, SouthWestern Publishers, Mason, Ohio, p. 900.

6. Callaghan, J., R. Kleiman and A. Sahu. (1999). The Market-Adjusted Investment Performance of ADR IPOs and SEOs. Global Finance Journal. 10: 123-145.

7. Dawson, S. (1987). The Secondary Stock Market Performance of Initial Public Offerings in Hong Kong, Singapore and Malaysia: 1978-1984. Journal of Business, Finance \& Accounting. 14: 65-76.

8. Elliott, S. and Mark Schaub. (2005). Foreign Financial Institution Equities: Returns From Emerging Markets and Developed Markets Differ. International Business \& Economics Research Journal. 4: 13-20.

9. Elliott, S. and Mark Schaub. (2008). American Depository Receipts: A Case Study of the Performance of Foreign Manufacturing Firm Equities Listed on the New York Stock Exchange. Journal of Business Case Studies. 4: 49-59.

10. Foerster, S. and G. Andrew Karolyi. (2000). The Long-Run Performance of Global Equity Offerings. Journal of Financial and Quantitative Analysis. 35: 499-528.

11. Huang, Y. (1999). The Price Behavior of Initial Public Offerings on the Taiwan Stock Exchange. Applied Financial Economics. 9: 201-208.

12. Jiang, C. (1998). Diversification with American Depository Receipts: The Dynamics and the Pricing Factors. Journal of Business, Finance \& Accounting. 25: 683-699.

13. Levis, M. (1993). The Long-Run Performance of Initial Public Offerings: The UK Experience 1980-1988. Financial Management. 22: 28-42.

14. Officer, D. and R. Hoffmeister. (1988). ADRs: A Substitute for the Real Thing? Journal of Portfolio Management. 15: 61-65.

15. Ritter, J. (1991). The Long-Run Performance of Initial Public Offerings. Journal of Finance. 46: 3-27. 
16. Schaub, M. (2002). Hazardous to Your Wealth? The Early and Long-Term Performance of Mexican ADRs on the New York Stock Exchange. Journal of Asset Management. 3: 9-16.

17. Schaub, M. (2003). Investment Performance of American Depository Receipts Listed on the New York Stock Exchange: Long and Short. Journal of Business and Economic Studies. 9:1-19.

18. Schaub, M. and M. Highfield. (2006). Market Timing Wealth Effects of American Depository Receipts: The Cases of Emerging and Developed Market Issues. Journal of International Financial Markets, Institutions \& Money. 16: 270-282.

19. Schaub, M. (2008). A Note on the Performance of Chinese American Depository Receipts. Applied Economics Letters. http//www.tandf.co.uk/journals.

20. Sundaram, A. and D. Logue. (1996). "Valuation Effects of Foreign Company Listings on U.S. Exchanges." Journal of International Business Studies. 27: 67-89.

21. Surz, Ronald J. (2007). "Stock Diversification in the $21^{\text {st }}$ Century." Journal of Financial Service Professionals. 61: 14-17.

22. The World Factbook, 2008. https://www.cia.gov/library/publications/the-world-factbook/geos/ci.html. (accessed July 18, 2008). 
Table 1

Early Return Performance By Day For Chilean ADRs Issued From January 1987 Through December 2001 on the NYSE

\begin{tabular}{|c|c|c|c|c|c|c|c|c|c|c|c|c|}
\hline \multirow[b]{2}{*}{ Day } & \multicolumn{4}{|c|}{ Entire Sample $(\mathrm{Obs}=24)$} & \multicolumn{4}{|c|}{$\underline{\text { SEO ADRs }(\mathrm{Obs}=5)}$} & \multicolumn{4}{|c|}{$\underline{\text { IPO ADRs }(\mathrm{Obs}=19)}$} \\
\hline & XR & $\begin{array}{l}\mathrm{p}- \\
\text { value }\end{array}$ & CXR & $\begin{array}{l}\mathrm{p}- \\
\text { value }\end{array}$ & $\mathrm{XR}$ & $\begin{array}{l}\mathrm{p}- \\
\text { value }\end{array}$ & CXR & $\begin{array}{l}\mathrm{p}- \\
\text { value }\end{array}$ & $\mathrm{XR}$ & $\begin{array}{l}\mathrm{p}- \\
\text { value }\end{array}$ & CXR & $\begin{array}{l}\mathrm{p}- \\
\text { value }\end{array}$ \\
\hline D1 & $0.47 \%$ & 0.16 & $0.47 \%$ & 0.16 & $0.92 \%$ & 0.13 & $0.92 \%$ & 0.13 & $0.35 \%$ & 0.27 & $0.35 \%$ & 0.27 \\
\hline D2 & $-0.23 \%$ & 0.29 & $0.24 \%$ & 0.35 & $1.63 \%$ & 0.04 & $2.55 \%$ & 0.02 & $-0.72 \%$ & 0.03 & $-0.37 \%$ & 0.30 \\
\hline D3 & $0.52 \%$ & 0.13 & $0.76 \%$ & 0.16 & $2.18 \%$ & 0.02 & $4.73 \%$ & 0.00 & $0.08 \%$ & 0.43 & $-0.29 \%$ & 0.36 \\
\hline D4 & $-0.09 \%$ & 0.41 & $0.67 \%$ & 0.22 & $1.13 \%$ & 0.17 & $5.86 \%$ & 0.00 & $-0.41 \%$ & 0.12 & $-0.70 \%$ & 0.22 \\
\hline D5 & $0.09 \%$ & 0.42 & $0.76 \%$ & 0.22 & $-1.06 \%$ & 0.12 & $4.80 \%$ & 0.02 & $0.39 \%$ & 0.22 & $-0.31 \%$ & 0.38 \\
\hline D6 & $-0.53 \%$ & 0.07 & $0.23 \%$ & 0.41 & $-0.49 \%$ & 0.34 & $4.31 \%$ & 0.05 & $-0.54 \%$ & 0.07 & $-0.85 \%$ & 0.22 \\
\hline D7 & $-0.57 \%$ & 0.08 & $-0.34 \%$ & 0.38 & $-0.12 \%$ & 0.44 & $4.18 \%$ & 0.07 & $-0.69 \%$ & 0.06 & $-1.53 \%$ & 0.10 \\
\hline D8 & $0.10 \%$ & 0.41 & $-0.24 \%$ & 0.42 & $-0.31 \%$ & 0.41 & $3.88 \%$ & 0.10 & $0.21 \%$ & 0.31 & $-1.32 \%$ & 0.15 \\
\hline D9 & $0.54 \%$ & 0.14 & $0.30 \%$ & 0.41 & $3.06 \%$ & 0.03 & $6.94 \%$ & 0.03 & $-0.12 \%$ & 0.37 & $-1.44 \%$ & 0.14 \\
\hline D10 & $-0.04 \%$ & 0.47 & $0.26 \%$ & 0.43 & $2.74 \%$ & 0.07 & $9.68 \%$ & 0.01 & $-0.77 \%$ & 0.03 & $-2.21 \%$ & 0.05 \\
\hline D11 & $-0.02 \%$ & 0.48 & $0.25 \%$ & 0.43 & $-0.73 \%$ & 0.06 & $8.95 \%$ & 0.01 & $0.17 \%$ & 0.32 & $-2.05 \%$ & 0.08 \\
\hline D12 & $-0.09 \%$ & 0.41 & $0.16 \%$ & 0.46 & $-0.12 \%$ & 0.46 & $8.83 \%$ & 0.02 & $-0.08 \%$ & 0.43 & $-2.12 \%$ & 0.08 \\
\hline D13 & $-0.20 \%$ & 0.28 & $-0.05 \%$ & 0.49 & $-0.37 \%$ & 0.32 & $8.47 \%$ & 0.03 & $-0.16 \%$ & 0.34 & $-2.29 \%$ & 0.07 \\
\hline D14 & $-0.29 \%$ & 0.19 & $-0.33 \%$ & 0.42 & $0.25 \%$ & 0.40 & $8.72 \%$ & 0.02 & $-0.43 \%$ & 0.09 & $-2.71 \%$ & 0.04 \\
\hline D15 & $0.51 \%$ & 0.08 & $0.17 \%$ & 0.46 & $0.42 \%$ & 0.21 & $9.13 \%$ & 0.02 & $0.53 \%$ & 0.12 & $-2.18 \%$ & 0.09 \\
\hline D16 & $-0.07 \%$ & 0.44 & $0.11 \%$ & 0.47 & $-1.08 \%$ & 0.04 & $8.05 \%$ & 0.04 & $0.20 \%$ & 0.36 & $-1.98 \%$ & 0.12 \\
\hline D17 & $0.73 \%$ & 0.07 & $0.84 \%$ & 0.32 & $-0.54 \%$ & 0.22 & $7.51 \%$ & 0.05 & $1.07 \%$ & 0.04 & $-0.92 \%$ & 0.31 \\
\hline D18 & $0.16 \%$ & 0.32 & $1.00 \%$ & 0.29 & $0.67 \%$ & 0.17 & $8.18 \%$ & 0.04 & $0.03 \%$ & 0.47 & $-0.89 \%$ & 0.32 \\
\hline D19 & $-0.57 \%$ & 0.07 & $0.43 \%$ & 0.41 & $-1.48 \%$ & 0.13 & $6.70 \%$ & 0.08 & $-0.33 \%$ & 0.18 & $-1.22 \%$ & 0.26 \\
\hline D20 & $-0.85 \%$ & 0.06 & $-0.42 \%$ & 0.41 & $-2.51 \%$ & 0.07 & $4.19 \%$ & 0.21 & $-0.41 \%$ & 0.21 & $-1.63 \%$ & 0.20 \\
\hline D21 & $-0.13 \%$ & 0.38 & $-0.55 \%$ & 0.39 & $0.46 \%$ & 0.23 & $4.66 \%$ & 0.19 & $-0.29 \%$ & 0.29 & $-1.92 \%$ & 0.17 \\
\hline
\end{tabular}

The computation of average excess returns (XR) is described in equation 2 in the text and the computation of cumulative excess returns (CXR) is described in equation 3 in the text. P-values in bold italics represent returns that are significant at the $10 \%$ alpha level. 
Table 2

Long-Term Performance by Month for Chilean ADRs Listed on the NYSE (January 1987 - December 2001)

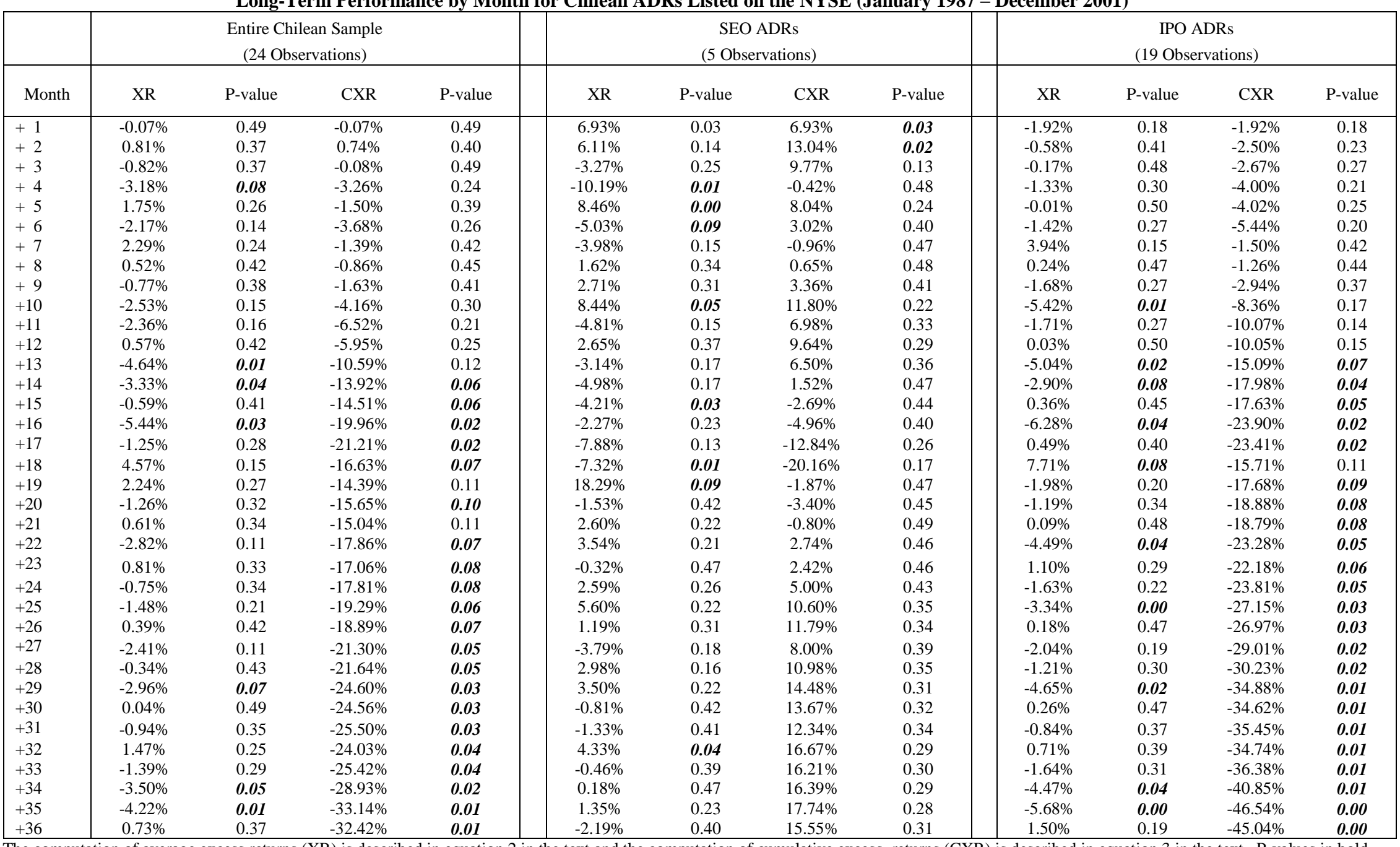

The computation of average excess returns (XR) is described in equation 2 in the text and the computation of cumulative excess returns (CXR) is described in equation 3 in the text. P-values in bold italics represent returns that are significant at the $10 \%$ alpha level. 
NOTES 